\title{
Application and Practice of Project Teaching Method in Teaching of Chemical Engineering Specialty Course
}

\author{
Wang-xi Fan ${ }^{1, a^{*}}$, Ze-fang $\mathrm{Li}^{2, \mathrm{~b}}$, Zhong-mei Huang ${ }^{1, \mathrm{c}}$ \\ ${ }^{1}$ Department of Chemical and Environmental Engineering, Wuhan Bioengineering Institute, Wuhan, \\ 430415, China \\ ${ }^{2}$ Institute of Computer Technology and Software Engineering, Wuhan Polytechnic, Wuhan, 430074, \\ China \\ aemail:12320575@qq.com, bemail:408729494@qq.com, cemail:504594481@qq.com, \\ * corresponding author
}

Keywords: project teaching; practice; chemical engineering specialty; vocational education; transformation and development.

\begin{abstract}
This investigation aims to further study the application and implementation of project teaching method in the teaching of chemical engineering specialty course, such as "organic chemistry" and "fine chemicals chemistry" course. The application of project teaching method in the teaching of organic chemistry course is systematic discussed in this study. A complete project system for organic chemistry course is established. Based on the comprehensive discussion of 4 stages of the implementation of project, it is reasonable to infer that the vigorously promotion and widely application of project teaching method will be one of the most efficient methods in the development of applied talents training mode.
\end{abstract}

\section{Introduction}

The vocational education of Germany has always been famous for its high quality, which is closely related to the reasonable and efficient application of the project teaching method [1] [2]. Project teaching method originated in the United States since 1920s. It has been widely promoted as a typical action oriented teaching methods due to high efficiency, applicability and maneuverability by many vocational colleges and enterprises since 1980s in Germany [3][4][5]. Project teaching is a universally applicable method with strong practice, which achieves the teaching objectives by design and implementation of specific projects with integrating teaching contents. In which, all students are the main body and the center. The traditional classroom teaching mode with teacher centered is completely changed in this method. Moreover, cooperation ability and practical ability of student can be effectively cultivated by "learning by practice" and "practice by learning". Therefore, it is a widely used practical teaching method in some developed countries, such as America, Germany, France, United Kingdom and others [6][7][8].

The cultivation of applied engineering talents in colleges in China has been greatly developed due to the introduction of project teaching method. Many similar teaching methods were adopted in many colleges and training institutions, such as Henan Institute of Engineering, Hebei Science and Technology College, Shandong Provincial Cadre Management College, Wuxi Institute of Technology and so on [9][10][11]. At present, these similar teaching methods mostly were applied in teaching of animation, machinery, foreign language, marketing, management and other professional theory and practical training courses. It is gratifying that relatively good teaching results has achieved due to the using of these methods [12]. However, the systematic application and research of project teaching method in the teaching of chemical engineering specialty course has never been reported in the literature. This investigation aims to further study the application and implementation of project teaching method in the teaching of chemical engineering specialty course, such as "organic chemistry" and "fine chemicals chemistry" course. 


\section{The Practice of Project Teaching in Organic Chemistry}

Introduction to Organic Chemistry. "Organic chemistry" is a basic subject, which mainly study and discuss the composition, structure, properties and change rules of discipline of organic compounds. It is an important professional courses with high practicality for students of chemical engineering specialty. Moreover, it plays an irreplaceable role in curriculum system of the organic chemical industry, fine chemical industry, chemical engineering, polymer materials and engineering speciality and so on. It is especially worth to note that organic chemistry can provide a solid base for the subsequent study. As the main research objects of organic chemistry, saturated and unsaturated hydrocarbons, aromatic hydrocarbons, halogenated hydrocarbons, alcohols, aldehydes, ketones, phenol ethers, carboxylic acid and its derivatives and other organic chemical products are closely related to our real life. In which, almost all of the organic chemical products have been large-scale industrial produced and commercialized via relatively perfect production process. Based on these premises, it is reasonable to infer that organic chemistry course has the potential advantages of implementing "project teaching".

Preparation and Design of Project. The analysis of knowledge requirement, the decomposition of the knowledge and the construction of specific project are the key steps in the implementation of the project teaching method. The knowledge are skillfully integrate into one or more specific project after the gaps between teaching content and enterprise were deeply analyzed by faculty adviser. Students or learning groups can independently and quickly complete the project due to their autonomy and exploratory learning under the guidance of teachers [13][14][15]. So there the purpose of imparting knowledge and learning skills is subtly achieved.

Seven feasible projects were integrated and designed for "organic chemistry" course after a comprehensive analysis of the common organic chemical products in the market and organic chemistry textbook. These projects take into account not only the inheritance of organic chemistry knowledgebut also the actual market applications of organic chemical products. The projects with practiced and optimized are summarized in Table 1.

Table 1 Seven projects of Organic Chemistry Course

\begin{tabular}{|c|c|c|c|}
\hline No. & Project name & Coverage of knowledge & Class hours \\
\hline 1 & $93 \#$ or $97 \#$ (Selection of gasoline) & Saturated hydrocarbon & 4 \\
\hline 2 & What is "white trash"? & unsaturated hydrocarbon & 4 \\
\hline 3 & “Three benzene” in industry & Aromatic hydrocarbon & 8 \\
\hline 4 & $\begin{array}{l}\text { Bridge for translating of organic } \\
\text { compounds }\end{array}$ & Halogenated hydrocarbon & 8 \\
\hline 5 & $\begin{array}{l}\text { Alcohol testing instrument in the } \\
\text { investigation of drunk driving }\end{array}$ & Alcohol, phenolic, ether & $4-8$ \\
\hline 6 & Preparation of PMMA (organic glass) & Aldehyde ketone & $4-8$ \\
\hline 7 & $\begin{array}{l}\text { Antiseptic and antibacterial agent: } \\
\text { sorbic acid }\end{array}$ & $\begin{array}{l}\text { Carboxylic acids and their } \\
\text { derivatives }\end{array}$ & 8 \\
\hline 8 & self-selected project & If necessary, temporary design. & $4-8$ \\
\hline
\end{tabular}

The coverage of knowledge and the principles of easy to difficult and gradual should be fully reflected in the proceeding of project design. At the same time, the implementation stages and levels of the project should be fully considered.

Implementation Of Project. 48 to 64 class hours are usually set for the "organic chemistry" course of chemical engineering specialty, which aims to training applied talents. Taking into account the operability of all the project of organic chemistry course, the first 8 class hours is arranged to carry out theoretical teaching. In which, the basic knowledge, basic concepts and basic research methods are briefly introduced by the teacher, so that students have a preliminary understanding for those. And then, each project is completed in 1 or 2 weeks (ca. 4-8 class hours) starting from the 9th class hours. The all projects shown in table 1 will be completed in a whole semester. The designated or optional projects will be completed through the integration of the knowledge of the application by 
students or learning groups. The allocation of class hours in detail is summarized in Table 1 . The implementation of every project is divided into the following 4 stages:

Stage 1: Explanation and Decomposition of Project. Prior to implementation of the project, the objective and significance of the project, the coverage of knowledge points should be explained in detail by a guidance teacher. Moreover, the analysis of knowledge requirement are preached briefly. At the same time, the guidance teacher should not only encourage students to use divergent thinking, give full play to the imagination and innovative learning, but also require students to pay attention to the scientific nature, rigor and integrity of knowledge system. The tasks of the project are decomposed according to the characteristics of the team members by each project team leader. The role of each team member, cooperative mode and every time node of each task are defined.

Stage 2: Information Searching. The success or failure of the project implementation is determined directly by the quality of information searching. All team members should be involved in the process of information searching. In order to improve quality of acquired information as much as possible, the appropriate information according to the main body of the project are selected elaborately and deeply discussed by everyone in the group. The completion with independence or collaboration of the project is the core step in this stage.

Stage 3: Project Design The stage of project design is the core section in the whole project implementation process. In this stage, all team members should contribute their own idea, should participate in the discussion of the design of the companion. They have to search more appropriate information if necessary. Finally, a summary report or design plan that can be submitted was sorted and optimized. The teachers and enterprise personnels can provide guidance on professional knowledge and product market in this stage, respectively.

Stage 4: Group Communication and Project Evaluation. Project evaluation was carried out in the process of group communication. Relevant business management or technical personnel were invited to participate in this stage. The communication was presided over by the teacher. In which, the achievement of student and/or the quality of project were evaluated from the following four aspect: student self- evaluation, classmate evaluation, teacher evaluation, enterprises evaluation.

Representative selected by each group should share or display their own project design and the gains or losses in the implementation process of the project one by one via multimedia equipment. At the same time to complete student self- evaluation. And then, recommendations or opinions on the work of the project group are made by students from other groups, and provided the evaluation of the classmates. Subsequently, enterprises evaluation is carried out by relevant business management or technical personnel according to the actual application of organic chemical products or the actual operation of the production line. In the end, teacher evaluations are carried out according to the comprehensive utilization of knowledge, the solution of practical problems and innovative. Moreover, the improvement measures of the project should pointed out combined with the evaluation of enterprises by teacher. The scores of individual items in each group are composed of four parts mentioned above. The scores of individual items of each group are composed of four parts mentioned above.

The students will obtain a sense of achievement due to the successful implementation of the project, which will efficiently avoid arid study and life caused by the traditional teaching mode. It is conducive to fully mobilize the enthusiasm of students, to meet the students' desire to learn, to cultivate students' autonomous learning, ability to analyze and solve problems independently.

The specific tasks of students, teachers and enterprise personnels in various stages are summarized in Table 2.

\section{Conclusion}

The gap between the teaching of chemical engineering courses and the actual production of engineering will decrease rapidly. It is attributed to the vigorously promotion and widely application of project teaching method in the teaching of chemical engineering courses. Project teaching method is famous for the comprehensive training of students' team spirit and practical ability. The successful 
application of project teaching is not only beneficial to significantly reduce the distance between the factory and classroom, is advantageous to the realization of combination of teaching process and the production process, is convenient to the realization of combination of professional curriculum content and occupation standard, but also is convenient to advance contact the society for students. All these measures will provide a good foundation for students to go to work in the future.

Based on the market orientation of student employment and the characteristics of project teaching, it is reasonable to infer that the vigorously promotion and widely application of project teaching method will be one of the most efficient methods in the development of applied talents training mode under promoting the transformation and development background at present.

Table 2. The specific tasks in various stages

\begin{tabular}{cccc}
\hline stage & $\begin{array}{c}\text { The specific tasks of } \\
\text { students }\end{array}$ & $\begin{array}{c}\text { The specific tasks of } \\
\text { teachers }\end{array}$ & $\begin{array}{c}\text { The specific tasks of } \\
\text { enterprise personnels }\end{array}$ \\
\hline 1 & $\begin{array}{c}\text { Free group pair; } \\
\text { Role assignment; } \\
\text { Task decomposition }\end{array}$ & $\begin{array}{c}\text { Explan related knowledge } \\
\text { and its coverage; } \\
\text { Determine the purpose of } \\
\text { the task }\end{array}$ & $\begin{array}{c}\text { Provide knowledge } \\
\text { requirement }\end{array}$ \\
\hline 2 & $\begin{array}{c}\text { The inquiry, selection } \\
\text { and processing of } \\
\text { Information. }\end{array}$ & $\begin{array}{c}\text { Provide guidance on } \\
\text { technology }\end{array}$ & $\begin{array}{c}\text { Provide industry related } \\
\text { information }\end{array}$ \\
\hline 3 & $\begin{array}{c}\text { The design, revised and } \\
\text { optimization of project; } \\
\text { Complete the final } \\
\text { project plan }\end{array}$ & $\begin{array}{c}\text { Provide guidance on } \\
\text { professional knowledge }\end{array}$ & $\begin{array}{c}\text { Provide guidance on } \\
\text { product market }\end{array}$ \\
& $\begin{array}{c}\text { Share results } \\
\text { Exchange experience } \\
\text { Self evaluation }\end{array}$ & $\begin{array}{c}\text { Teacher evaluation; } \\
\text { Suggestions for } \\
\text { improvement }\end{array}$ & $\begin{array}{c}\text { Enterprises evaluation; } \\
\text { Suggestions for } \\
\text { improvement }\end{array}$ \\
\hline
\end{tabular}

\section{Acknowledgments}

The authors would like to thank the referees for their valuable comments and suggestions. This work was supported by the Education Department of Hubei Province (No. 2013395).

\section{References}

[1] R. G. Burgess, Project Teaching in the Sociology of Education: A Case Study. Teac. Soci. 2 (1979) 179-194.

[2] G. M. Montes, M. D. C. R. GáMez, B. M. Escobar, J. O. GarcíA, Final Project Teaching in Higher Education within Civil Engineering: New Perspective. J. Prof. Issu. Eng. Educ. Pract. 2 (2007) 94-98.

[3] S. B. Ransom, The science fair as an aid to project teaching. Sci. Educ. 3 (2006) 133-138.

[4] K. Kataoka, M. Taguchi, A. Takeshita, The Study and Practice of Project Teaching of Comprehensive Training in Mould Major. Liaon. High. Voca. Tech. Ins. J. 3 (2011) 295-297.

[5] M. Wang, M. Zhou, Development of the training program for excellent advanced manufacturing technology engineers by project-teaching method. Chi. Mod. Educ. Equi. 10 (2010) 32-35.

[6] G. H. Traftost, Project Teaching in General Science 1. Sch. Sci. Math. 4 (2010) 315-322.

[7] A. Sa-Ngiamwibool, Raising learner awareness of local wisdom in tour-related project teaching. Indo. J. Appl. Ling. 2 (2012) 1-16. 
[8] L. H. Tong, W. U. Jian, Study and Practice on the Project Teaching Based on the Course of The Chemical Equipment Application and Maintenance. Guan. Chem. Ind. 19 (2015) 31-37.

[9] X. Fang, D. Jiang, K. V. Amp, The Research on the Application of Project Teaching Method in Analysis and Detection of Oil Products. Shan. Chem. Ind. 24 (2015) 56-59.

[10] S. Q. Zhang, Project Setting and Content Design of Project Teaching Method in "Product-oriented, Project Progressive" MCU Course. J. Chan. Vocat. Coll. of Inform. Tech. 4 (2010) 166-169.

[11] W. X. Fan, Z. F. Li, Current situation and Countermeasures of teachers' Continuing Education in private colleges in Hubei Province. Conti. Edu. Res. 3 (2012) 97-99.

[12] J. Cao, N. V. University, Project Teaching Reform for The Course of CNC Equipment Diagnosis and Maintenance Based on an Integration of Virtual and Real Platforms. J. Nan. Text. Vocat. Tech. Coll. 02 (2014) 89-92.

[13] Q. Wan, G. R. Sui, Guiding an Active Role of University New Media Communication-New Media Quality Education. J. HuBei TV Uni. 6 (2013) 27, 51.

[14] X. Q. Zhu, J. W. Hu, H. Zeng, H. H. Chen, Research on micro-project driven teaching method with CDIO engineering educational pattern. Exper. Tech. Manag. 11 (2012) 159-161.

[15] K. R. Wang, Application of project teaching method in course of Chinese medical preparation. Chi. Medi. Hera. 33 (2012) 160-161. 